\title{
Front Matter: Volume 11237
}

, "Front Matter: Volume 11237," Proc. SPIE 11237, Biophotonics in Exercise Science, Sports Medicine, Health Monitoring Technologies, and Wearables, 1123701 (5 March 2020); doi: 10.1117/12.2569913

SPIE. Event: SPIE BiOS, 2020, San Francisco, California, United States 


\title{
Biophotonics in Exercise Science, Sports Medicine, Health Monitoring Technologies, and Wearables
}

Babak Shadgan

Amir H. Gandjbakhche

Editors

\author{
1-2 February 2020 \\ San Francisco, California, United States
}

Sponsored by

SPIE

Cosponsored by

Hamamatsu Corporation (United States)

Published by

SPIE 
The papers in this volume were part of the technical conference cited on the cover and title page. Papers were selected and subject to review by the editors and conference program committee. Some conference presentations may not be available for publication. Additional papers and presentation recordings may be available online in the SPIE Digital Library at SPIEDigitalLibrary.org.

The papers reflect the work and thoughts of the authors and are published herein as submitted. The publisher is not responsible for the validity of the information or for any outcomes resulting from reliance thereon.

Please use the following format to cite material from these proceedings:

Author(s), "Title of Paper," in Biophotonics in Exercise Science, Sports Medicine, Health Monitoring Technologies, and Wearables, edited by Babak Shadgan, Amir H. Gandjbakhche, Proceedings of SPIE Vol. 11237 (SPIE, Bellingham, WA, 2020) Seven-digit Article CID Number.

ISSN: 1605-7422

ISSN: 2410-9045 (electronic)

ISBN: 9781510632370

ISBN: 9781510632387 (electronic)

Published by

SPIE

P.O. Box 10, Bellingham, Washington 98227-0010 USA

Telephone +1 3606763290 (Pacific Time) · Fax +1 3606471445

SPIE.org

Copyright (c) 2020, Society of Photo-Optical Instrumentation Engineers.

Copying of material in this book for internal or personal use, or for the internal or personal use of specific clients, beyond the fair use provisions granted by the U.S. Copyright Law is authorized by SPIE subject to payment of copying fees. The Transactional Reporting Service base fee for this volume is $\$ 21.00$ per article (or portion thereof), which should be paid directly to the Copyright Clearance Center (CCC), 222 Rosewood Drive, Danvers, MA 01923. Payment may also be made electronically through CCC Online at copyright.com. Other copying for republication, resale, advertising or promotion, or any form of systematic or multiple reproduction of any material in this book is prohibited except with permission in writing from the publisher. The CCC fee code is $1605-$ $7422 / 20 / \$ 21.00$.

Printed in the United States of America by Curran Associates, Inc., under license from SPIE.

Publication of record for individual papers is online in the SPIE Digital Library.

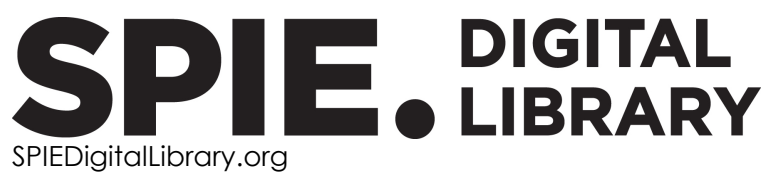

Paper Numbering: Proceedings of SPIE follow an e-First publication model. A unique citation identifier (CID) number is assigned to each article at the time of publication. Utilization of CIDs allows articles to be fully citable as soon as they are published online, and connects the same identifier to all online and print versions of the publication. SPIE uses a seven-digit CID article numbering system structured as follows:

- The first five digits correspond to the SPIE volume number.

- The last two digits indicate publication order within the volume using a Base 36 numbering system employing both numerals and letters. These two-number sets start with $00,01,02,03,04$, 05, 06, 07, 08, 09, 0A, OB ... 0Z, followed by 10-1Z, 20-2Z, etc. The CID Number appears on each page of the manuscript. 


\title{
Contents
}

\author{
$\checkmark \quad$ Authors \\ vii Conference Committee
}

WEARABLE OPTICAL SENSING TECHNIQUES I

1123702 A wearable time domain near infrared spectroscopy system [11237-1]

1123703 Ambient noise reduction in cerebral near infrared spectroscopy based on frequency division multiplexing [1 1237-2]

1123705 Smell detection could be traced in fNIRS signals recorded from the forehead [11237-4]

1123706 Combined low-frequency EEG and NIRS during hypoxia [1 1237-5]

\section{PHYSIOLOGICAL PARAMETER SENSING}

11237 OC Cerebral hemodynamic effects of 30-minute supine rest and postural changes at normoxia and hypoxia using near infrared spectroscopy [11237-10]

11237 OD Identification of human brown/beige adipose tissue using near-infrared time-resolved spectroscopy [11237-11]

$11237 \mathrm{OE} \quad$ Effects of normobaric hypoxia on cardiac mechanical function using seismocardiography [11237-12]

11237 OF The effects of acute hypoxia on heart rate variability parameters [11237-13]

\section{OPTICAL MONITORING OF MUSCLE METABOLISM AND FUNCTION}

11237 ON Real-time detection of fatigue effect on active muscle hemodynamics using diffuse correlation spectroscopy [11237-22]

1123700 Comparison of forearm muscle oxygenation dynamics during isometric and isotonic contractions monitored by near-infrared spectroscopy [11237-23]

$112370 Q \quad$ Limited muscle oxygen diffusive transport during exercise in humans [1 1237-25] 
BODY FUNCTION AND HEALTH MONITORING

11237 OR Optical evaluation of microvascular function at early and chronic stages of diabetes [11237-26]

11237 OT Simultaneous functional near infrared spectroscopy of the brain and bladder [1 1237-28] 


\title{
Authors
}

Numbers in the index correspond to the last two digits of the seven-digit citation identifier (CID) article numbering system used in Proceedings of SPIE. The first five digits reflect the volume number. Base 36 numbering is employed for the last two digits and indicates the order of articles within the volume. Numbers start with 00, 01, 02, 03, 04, 05, 06, 07, 08, 09, OA, OB...0Z, followed by 10-1Z, 20-2Z, etc.

\author{
Amagasa, Shiho, OD \\ Askari, Shahbaz, 03, 06 \\ Bastany, Zoya, 03, 06 \\ Bronkhorst, Mathijs, OT \\ Buttafava, M., 02 \\ Cheung, A., 00 \\ Contini, D., 02 \\ Dalla Mora, A., 02 \\ Dumont, Guy A., 03, 06 \\ Endo, Tasuki, OD, OQ \\ Fuse, Sayuri, $0 D, O Q$ \\ Gorji, Ali, 06 \\ Hamaoka, Takafumi, $\mathrm{OD}, \mathrm{OQ}$ \\ Holsti, Liisa, 06 \\ Ichinose, Masashi, ON, OR \\ Khoneiveh, Sepideh, 05 \\ Kime, Ryotaro, OD, OQ \\ Kuroiwa, Miyuki, OD, $O Q$ \\ Kurosawa, Yuko, OD, OQ \\ Lacerenza, M., 02 \\ Macnab, Andrew J., OT \\ Mirmobini, Soroush, 05 \\ Moein, Shima T., 05 \\ Nakabayashi, Mikie, ON, OR \\ Neary, J. Patrick, OC, OE, OF \\ Nozaki, K., ON \\ Ono, Yumie, ON, OR \\ Pagano, Roberto, 03 \\ Pifferi, A., 02 \\ Pourrezaei, Kambiz, 05 \\ Quarrie, David Mac, OC, OE, OF \\ Renna, M., 02 \\ Sahragard, F., 00 \\ Sasaki, Shotaro, OR \\ Shadgan, B., 00 \\ Singh, Jyotpal, OC, OE, OF \\ Stothers, Lynn, OT \\ Tanaka, Riki, OD, OQ \\ Teckchandani, Taylor A., OC, OE, OF \\ Torricelli, A., 02 \\ Tosi, A., 02 \\ Tu, L., 0 O \\ van Dongen, Isabelle, OT \\ Wong, Ardy, 05 \\ Zakeri, Issa, 05 \\ Zappa, F., 02
}


Proc. of SPIE Vol. 11237 1123701-6

Downloaded From: https://www.spiedigitallibrary.org/conference-proceedings-of-spie on 26 Apr 2023 Terms of Use: https://www.spiedigitallibrary.org/terms-of-use 


\section{Conference Committee}

Symposium Chairs

Jennifer K. Barton, The University of Arizona (United States)

Wolfgang Drexler, Medizinische Universität Wien (Austria)

Program Track Chairs

Tuan Vo-Dinh, Fitzpatrick Institute for Photonics, Duke University (United States)

Anita Mahadevan-Jansen, Vanderbilt University (United States)

Conference Chairs

Babak Shadgan, International Collaboration on Repair Discoveries (Canada)

Amir H. Gandjbakhche, Eunice Kennedy Shriver National Institute of Child Health and Human Development (United States)

\section{Conference Program Committee}

Willy N. J. M. Colier, Artinis Medical Systems B.V. (Netherlands)

Marco Ferrari, Università degli Studi dell'Aquila (Italy)

Takafumi Hamaoka, Tokyo Medical University (Japan)

Andrew J. Macnab, The University of British Columbia (Canada)

Anita Mahadevan-Jansen, Vanderbilt University (United States)

Patrick Neary, University of Regina (Canada)

Lonnie Petersen, University of California, San Diego (United States)

T. Joshua Pfefer, U.S. Food and Drug Administration (United States)

W. Darlene Reid, University of Toronto (Canada)

Behrouz Shabestari, National Institute of Biomedical Imaging and Bioengineering (United States)

Robert V. Warren, Beckman Laser Institute and Medical Clinic (United States)

Session Chairs

1 Wearable Optical Sensing Techniques I

Amir H. Gandjbakhche, National Institutes of Health (United States)

Babak Shadgan, International Collaboration on Repair Discoveries (Canada) 
2 Wearable Optical Sensing Techniques II

Robert V. Warren, Beckman Laser Institute and Medical Clinic (United States)

Takafumi Hamaoka, Tokyo Medical University (Japan)

3 Physiological Parameter Sensing

Andrew J. Macnab, The University of British Columbia (Canada)

4 Sport and Exercise Monitoring

Takafumi Hamaoka, Tokyo Medical University (Japan)

J. Patrick Neary, University of Regina (Canada)

5 Optical Monitoring of Muscle Metabolism and Function

Babak Shadgan, International Collaboration on Repair Discoveries

(Canada)

J. Patrick Neary, University of Regina (Canada)

6 Body Function and Health Monitoring

Amir H. Gandjbakhche, National Institutes of Health (United States)

Andrew J. Macnab, The University of British Columbia (Canada) 